\title{
Moderasi Preferensi Risiko Pada Hubungan Kualitas Pelayanan Account Representative dan Kepatuhan WPOP
}

\author{
Ni Kadek Ayu Disnayanti ${ }^{1}$ \\ I.G.A. Agung Pradnya Dewi \\ ${ }^{1,2}$ Fakultas Ekonomi dan Bisnis Universitas Pendidikan Nasional (Undiknas), \\ Bali, Indonesia \\ e-mail: ayudisnayanti@gmail.com
}

\begin{abstract}
ABSTRAK
Penelitian ini bertujuan untuk mengetahui pengaruh kualitas pelayanan account representative terhadap kepatuhan wajib pajak orang pribadi dengan preferensi risiko sebagai variabel pemoderasi di Kantor Pelayanan Pajak Pratama Denpasar Timur.Jumlah sampel yang digunakan dalam penelitian ini adalah sebanyak 100 responden dari 76.543 populasi wajib pajak orang pribadi yang masih efektif di Kantor Pelayanan Pajak Pratama Denpasar Timur pada tahun 2017. Besarnya sampel dihitung berdasarkan rumus slovin dengan teknik penentuan sampel metode accidental sampling. Pengumpulan data dalam penelitian ini dilakukan dengan metode kuesioner. Teknik analisis data yang digunakan adalah moderated regression analysis (MRA). Hasil penelitian menunjukkan bahwa kualitas pelayanan account representative berpengaruh positif terhadap kepatuhan wajib pajak orang pribadi dan preferensi risiko memperlemah kepatuhan wajib pajakorang pribdi.
\end{abstract}

Kata kunci: Kualitas pelayanan, preferensi risiko, kepatuhan wajib pajak

\begin{abstract}
This study aims to determine the effect of account representative service quality on individual taxpayer compliance with risk preferences as a moderating variable at the East Denpasar Primary Tax Office. The population in this study were all individual taxpayers registered at the East Denpasar Primary Tax Office. The number of samples used in this study is as many as 100 respondents from 76,543 population of individual taxpayers who are still effective in the Pratama Tax Office East Denpasar in 2017. The size of the sample is calculated based on Slovin formula with accidental sampling method sampling technique. Data collection in this study was conducted by questionnaire method. The data analysis technique used is moderated regression analysis (MRA). The results showed that account representative service quality had a positive effect on individual taxpayer compliance and risk preferences weakened taxpayer compliance with personal persons.

Keywords: Service quality, risk preference, tax compliance
\end{abstract}

\section{PENDAHULUAN}

Sumber penerimaan negara yang digunakan untuk membiayai pengeluaran pemerintah dan pembangunan nasional, diantaranya berasal dari penerimaan pajak dan penerimaan bukan pajak. Penerimaan-penerimaan negara digunakan untuk 
Ni Kadek Ayu Disnayanti dan I.G.A. Agung Pradnya Dewi. Moderasi ...

pembangunan fasilitas umum, belanja negara, pembayaran gaji pegawai, dan sebagainya. Penerimaan ini secara tidak langsung akan meningkatkan kemakmuran dan kesejahteraan rakyat. Sesuai dengan data yang ada bahwa realisasi penerimaan pajak yang diperoleh negara belum memperoleh hasil yang maksimal. Tabel 1 menyajikan data realisasi penerimaan pajak tahun 2015 sampai dengan 2017.

Tabel 1.

Realisasi Penerimaan Pajak Tahun 2015-2017

\begin{tabular}{llll}
\hline Tahun & $\begin{array}{l}\text { Target Penerimaan } \\
\text { Pajak (Triliun } \\
\text { Rupiah) }\end{array}$ & $\begin{array}{l}\text { Realisasi } \\
\text { Penerimaan Pajak } \\
\text { (Triliun Rupiah) }\end{array}$ & $\begin{array}{l}\text { \% Realisasi } \\
\text { Penerimaan Pajak }\end{array}$ \\
\hline 2015 & 1.489 & 1.240 & $83,3 \%$ \\
2016 & 1.539 & 1.284 & $83,4 \%$ \\
2017 & 1.498 & 1.343 & $89,6 \%$ \\
\hline
\end{tabular}

Sumber: Data diolah, 2018

Berdasarkan Tabel 1 dilihat bahwa realisasi penerimaan negara pada sektor pajak dalam periode 2015 sebesar 83,3 persen, 83,4 persen pada tahun 2016 dan 89,6 persen pada 2017. Realisasi penerimaan pajak mengalami peningkatan setiap tahunnya namun peningkatan realisasi pajak tidak mencapai target yang telah ditetapkan.

Direktorat Jenderal Pajak selalu berupaya mengoptimalkan pelayanan untuk meningkatkan kepatuhan Wajib Pajak sehingga diharapkan dapat meningkatkan kesadaran dan keinginan masyarakat untuk tertib sebagai Wajib Pajak. Direktorat Jenderal Pajak sebagai pengurus yang ditunjuk oleh pemerintah untuk mengumpulkan penerimaan pajak telah melakukan reformasi perpajakan terhadap kebijakan perpajakan dan sistem administrasi perpajakan sehingga potensi penerimaan pajak dapat dikumpulkan secara optimal (Sondakh; Jullie Jeanette, 2017). 
Tingkat kepatuhan wajib pajak di Provinsi Bali dari tahun ke tahun mengalami fluktuasi, kendatipun Bali merupakan destinasi tujuan utama pariwisata yang sekaligus menjadi penyumbang pajak terbesar dari sektor pariwisata. Hal tersebut dapat dibuktikan dengan data yang diperoleh dari Kantor Pelayanan Pajak (KPP) Pratama Denpasar Timur. KPP Pratama Denpasar Timur merupakan instansi vertikal Direktorat Jenderal Pajak yang membawahi wilayah Kecamatan Denpasar Timur dan Kecamatan Denpasar Selatan, sehingga KPP Pratama Denpasar Timur memiliki jumlah wajib pajak terdaftar yang cukup besar. Tabel 2.menyajikan data tingkat kepatuhan wajib pajak orang pribadi yang terdaftar di KPP Pratama Denpasar Timur periode 2013 sampai dengan 2017.

Tabel 2.

Tingkat Kepatuhan Wajib Pajak Orang Pribadi di Kantor Pelayanan Pajak Pratama Denpasar Timur Tahun 2015-2017

\begin{tabular}{ccccc}
\hline Tahun & WPOP Terdaftar & $\begin{array}{c}\text { WPOP } \\
\text { Efektif }\end{array}$ & $\begin{array}{c}\text { WPOP yang } \\
\text { Menyampaikan SPT }\end{array}$ & $\begin{array}{c}\text { Kepatuhan } \\
\text { Pajak \% }\end{array}$ \\
\hline 2015 & 87.652 & 68.124 & 36.928 & 54,20 \\
2016 & 91.048 & 71.554 & 41.175 & 57,54 \\
2017 & 96.073 & 76.543 & 38.647 & 50,49 \\
\hline Sumber: KPP Pratame
\end{tabular}

Sumber: KPP Pratama Denpasar Timur, 2018

Berdasarkan Tabel 2 terlihat bahwa persentase kepatuhan wajib pajak orang pribadi yang berada di lingkungan KPP Pratama Denpasar Timur mengalami fluktuasi selama lima tahun terakhir. Persentase di tahun 2015 sebesar54,20 persen. Kemudian di tahun 2016 meningkat lagi menjadi 57,54 persen, tetapi di tahun 2017 mengalami penurunan menjadi 50,4 persen. Dapat disimpulkan, persentase kepatuhan wajib pajak orang pribadi yang terdaftar di KPP Pratama Denpasar Timur dalam rentang waktu lima tahun terakhir berada pada kisaran 50 persen. Tingkat kepatuhan wajib pajak KPP Pratama Denpasar 
Ni Kadek Ayu Disnayanti dan I.G.A. Agung Pradnya Dewi. Moderasi ...

Timur masih di bawah target kepatuhan pajak nasional yang ditetapkan Direktorat Jenderal Pajak sesuai dengan Surat Edaran Nomor SE-07/PJ/2016, yaitu sebesar 72,5 persen. Hal ini mengindikasikan bahwa tingkat kepatuhan wajib pajak masih rendah. Rendahya tingkat kepatuhan wajib pajak adalah masalah yang serius yang sering terjadi di banyak negara berkembang (Das-gupta, 2004).

Dalam rangka meningkatkan kepatuhan wajib pajak maka Direktorat Jenderal Pajak melakukan modernisasi administrasi perpajakan. Modernisasi administrasi perpajakan memberikan banyak perubahan mendasar mulai dari restrukturisasi organisasi sampai dengan pengembangan sumber daya manusia serta penggunaan teknologi informasi dalam administrasi perpajakan. Pada tahun 2006 ditetapkan kebijakan-kebijakan untuk mendukung pelaksanaan modernisasi administrasi perpajakan yang diantaranya adalah kebijakan pembentukkan account representative yang tertuang dalam Peraturan Menteri Keuangan No. 98/PMK.01/2006. Account representative adalah aparat pajak yang bertanggung jawab dalam pelaksanaan pelayanan dan pengawasan secara langsung untuk sejumlah wajib pajak tertentu yang telah ditugaskan kepadanya.

Kualitas pelayanan atau jasa yang dikehendaki wajib pajak sangat memengaruhi kepuasaan dan kepatuhan wajib pajak, sehingga jaminan kualitas pelayanan menjadi prioritas utama. Kepuasan dan kepatuhan wajib pajak dapat menjadi refleksi dari kinerja atau kualitas pelayanan Account Representative (AR) kepada wajib pajaknya. Secara umum kepuasan dan ketidakpuasan maupun kepatuhan dan ketidakpatuhan tersebut merupakan perbedaan antara harapan dan kenyataan kinerja atau kualitas pelayanan yang dirasakan (Prasetyo, 2012). 
Terdapat beberapa penelitian tentang Account Representative diantaranya penelitian yang dilakukan oleh Sadjiarto (2013) memiliki hasil dimana Account Representative berpengaruh terhadap kepatuhan wajib pajak orang pribadi. Penelitian Wardani (2011) juga menyatakan bahwa pelayanan account representative berpengaruh terhadap kepatuhan wajib pajak. Namun dalam Penelitian Suratningsih (2018)Account Representative tidak berpengaruh terhadap kepatuhan wajib pajak orang pribadi. Penelitian-penelitian terdahulu ini menunjukkan hasil yang berbeda-beda sehingga diduga ada faktor lain yang menginteraksi pengaruh kualitas layanan Account Representative terhadap kepatuhan wajib pajak orang pribadi.

Hal yang memengaruhi kepatuhan wajib pajak orang pribadi tidak hanya dapat dilihat dari kualitas pelayanan Account Representative, tetapi keputusan seorang wajib pajak dapat dipengaruhi oleh perilakunya terhadap risiko yang dihadapi (Torgler, 2003). Preferensi risiko seseorang merupakan salah satu komponen dari beberapa teori yang berhubungan dengan pengambilan keputusan termasuk kepatuhan pajak seperti teori harapan kepuasan dan teori prospek. Dalam konseptual preferensi risiko terdapat tiga cakupan yaitu menghindari risiko, netral dalam menghadapi risiko, dan suka mencari risiko. Sebuah penelitian mengungkapkan bahwa perilaku wajib pajak dalam menghadapi risiko tidak dapat dianggap remeh dalam kaitannya dengan kepatuhan (Aryobimo dan Cahyonowati, 2012). Risiko-risiko yang terdapat pada wajib pajak dalam kaitannya untuk peningkatan kepatuhan wajib pajak antara lain adalah risiko keuangan, risiko kesehatan, risiko sosial, risiko pekerjaan, dan risiko keselamatan. 
Ni Kadek Ayu Disnayanti dan I.G.A. Agung Pradnya Dewi. Moderasi ...

Inkonsistensi dari hasil-hasil penelitian terdahulu memotivasi peneliti untuk menguji kembali Kualitas Pelayanan Account Representative terhadap Kepatuhan Wajib Pajak Orang Pribadi dengan menambahkan Preferensi Risiko sebagai variabel pemoderasi.

Pajak merupakan iuran yang dibayarkan oleh rakyat kepada negara yang masuk dalam kas negara yang melaksanaannya mengacu pada undang-undang serta pelaksanaannya dapat dipaksakan tanpa adanya balas jasa. Iuran tersebut digunakan oleh negara untuk melakukan pembayaran atas kepentingan umum (Mardiasmo, 2016). Menurut Tresno, Indra (2012), pajak adalah iuran wajib yang diberlakukan pada setiap Wajib Pajak atas obyek pajak yang dimilikinya dan hasilnya diserahkan kepada pemerintah. Kemudian definisi pajak menurut Undang-Undang Nomor 16 Tahun 2009 tentang Perubahan Keempat atas Undang-Undang Nomor 6 Tahun 1983 tentang Ketentuan Umum dan Tata Cara Perpajakan pada Pasal 1 Ayat 1 berbunyi pajak adalah kontribusi wajib kepada negara yang terutang oleh orang pribadi atau badan yang bersifat memaksa berdasarkan undang-undang, dengan tidak mendapatkan imbalan secara langsung dan digunakan untuk keperluan negara bagi sebesar-besarnya kemakmuran rakyat. Dari ketiga definisi tersebut pajak dapat dikatakan sumber utama penerimaan negara yang memiliki peran penting dalam meningkatkan dan melaksanakan pembangunan nasional dengan tujuan meningkatkan kesejahteraan dan kemakmuran rakyat.

Teori atribusi dikembangkan oleh Fritz Heider yang meyatakan bahwa perilaku seseorang itu ditentukan oleh kombinasi antara kekuatan internal 
(internal forces), yaitu faktor-faktor yang berasal dari dalam diri seseorang dan kekuatan eksternal, yaitu faktor-faktor yang berasal dari luar (Arfan, I, 2010). Teori atribusi memiliki keterkaitan dengan preferensi risiko yang merupakan kekuatan internal seseorang, sedangkan yang memiliki keterkaitan dengan kekuatan eksternal yaitu kualitas pelayanan account representative.

Menurut Tresno, Indra (2012), pajak adalah iuran wajib yang diberlakukan pada setiap wajib pajak atas obyek pajak yang dimilikinya dan hasilnya diserahkan kepada pemerintah yang masuk ke dalam kas negara. Kemudian definisi pajak menurut Undang-Undang Nomor 16 Tahun 2009 tentang Perubahan Keempat atas Undang-Undang Nomor 6 Tahun 1983 tentang Ketentuan Umum dan Tata Cara Perpajakan pada Pasal 1 Ayat 1 berbunyi pajak adalah iuran wajib rakyat kepada negara yang terutang oleh orang pribadi atau badan yang bersifat memaksa berdasarkan undang-undang, dengan tidak mendapatkan imbalan secara langsung dan digunakan untuk keperluan negara berupa pembangunan nasional untuk meningkatkan kemakmuran rakyat.

Pelayanan yang berkualitas menurut Supadmi (2009) merupakan pelayanan terhadap wajib pajak dengan memberikan kepuasan akan layanan yang diberikan namun tetap dalam batas memenuhi standar pelayanan yang dapat dipertangungjawabkan serta harus dilakukan secara terus-menerus, sehingga menumbuhkan tingkat kepercayaan wajib pajak yang nantinya akan meningkatkan kepatuhan wajib pajak. Menurut Parasuraman dan Zeithaml (1988) terdapat lima dimensi yang digunakan dalam menilai suatu kualitas pelayanan, yaitu kehandalan 
Ni Kadek Ayu Disnayanti dan I.G.A. Agung Pradnya Dewi. Moderasi ...

(reliability), Ketanggapan (responsiveness), jaminan (assurance), empati (emphaty) dan wujud fisik (tangibility)

Muhammarsyah (2011) mengemukakan, Account representative adalah pegawai Direktorat Jenderal Pajak yang telah diberi kepercayaan, wewenang, dan tanggung jawab untuk memberikan fungsi pelayanan, fungsi pembinaan dan fungsi pengawasan secara langsung pada Wajib Pajak tertentu.

Rahayu (2010) mengatakan bahwa, kepatuhan perpajakan dapat didefinisikan sebagai suatu keadaan di mana Wajib Pajak memenuhi semua kewajiban perpajakan dan melaksanakan hak perpajakannya. Kepatuhan dalam memenuhi kewajiban perpajakan meliputi kepatuhan formal dan kepatuhan material. Wajib Pajak Orang Pribadi adalah subjek pajak yang memiliki penghasilan atas usaha sendiri yang penghasilannya di atas pendapatan tidak kena pajak (PTKP).

Pelayanan pada sektor perpajakan dapat diartikan sebagai pelayanan yangdiberikan oleh Direktorat Jenderal Pajak kepada wajib pajak untuk membantuwajib pajak memenuhi kewajiban perpajakannya (Masruroh, S., 2013).

Pelayanan yang berkualitas menurut (Supadmi, 2009), mengemukakan bahwa pelayanan dimana wajib pajak merasa puas terhadap pelayanan yang diberikan dan tetap dalam batas memenuhi standar pelayanan yang dapat dipertangungjawabkan serta harus dilakukan secara terus-menerus, sehingga timbul kepercayaan yang nantinya akan meningkatkan kepatuhan wajib pajak.

Account Representative diatur dalam Peraturan Menteri Keuangan Nomor 79/PMK.01/2015 Tahun 2015 Tentang Account Representative Pada Kantor 
Pelayanan Pajak. Kepatuhan Wajib Pajak memenuhi kewajiban perpajakannya akan meningkatkan penerimaan Negara dan pada gilirannya akan meningkatkan besarnya rasio pajak. Wajib Pajak yang puas akan dapat merubah perilakunya dalam membayar pajak, akhirnya tingkat kepatuhan Wajib Pajak juga dapat berubah. Semua hal tersebut bisa terjadi karena peranan dari Account representative (AR) yang dimana $\mathrm{AR}$ secara khusus fokus pada pekerjaan menganalisa dan memonitor kepatuhan pembayaran pajak setiap Wajib Pajak yang diawasinya. Pengawasan dan Konsultasi atau yang sering disingkat Waskon, adalah nama seksi dalam struktur organisasi kantor pelayanan pajak. Dalam satu KPP ada empat seksi Waskon I, Waskon II, Waskon III, Waskon IV. Masingmasing waskon dipimpin oleh seorang kepala seksi. Pada seksi Waskon inilah para Account representative (AR) berada, dan mereka bertanggung jawab kepala seksi yang menjadi atasan langsungnya.

Menurut Muhammarsyah (2011) mengemukakan bahwa account representative adalah pegawai Direktorat Jenderal Pajak yang diberi kepercayaan, wewenang, dan tanggung jawab untuk memberikan pelayanan, pembinaan dan pengawasan secara langsung pada Wajib Pajak tertentu.

Teori atribusi menjelaskan bahwa perilaku seseorang itu ditentukan oleh kombinasi antara kekuatan internal (internal forces) dan kekuatan eksternal.Berdasarkan teori atribusi, kualitas pelayanan account representative merupakan kekuatan eksternal dalam mendorong wajib pajak memenuhi kewajiban perpajakannya. Penelitian sebelumnya pernah dilakukan oleh Pandan (2014) mengemukakan bahwa pelayanan yang berkualitas harus diupayakan dapat 
Ni Kadek Ayu Disnayanti dan I.G.A. Agung Pradnya Dewi. Moderasi ...

memberi keamanan, kenyamanan, kelancaran dan kepastian hukum yang dapat dipertanggungjawabkan. Jika kualitas pelayanan oleh aparat pajak dilakukan seperti ini maka para wajib pajak akan merasa puas sehingga mereka akan lebih patuh dalam menyampaikan kewajiban perpajakannya. Hasil penelitian menunjukan bahwa variabel kualitas pelayanan berpengaruh positif dan signifikan terhadap kepatuhan wajib pajak.

Sedangkan menurut Rosady (2014) mengemukakan bahwa untuk meningkatkan kepatuhan perpajakan maka perlu memberikan kualitas pelayanan yang optimal terhadap wajib pajak seperti lebih meningkatkan kualitas dan kuantitas seperti menambahkan petugas pajak dibagian TPT (Tempat Pelayanan Terpadu) untuk melayani wajib pajak yang akan melaporkan SPT ataupun untuk membuat NPWP (Nomor Pokok Wajib Pajak) sehingga memenuhi kepuasan bagi wajib pajak. Apabila kualitas pelayanan pajak dilakukan secara optimal, maka akan meningkatkan tingkat kepatuhan perpajakan pada Wajib Pajak orang pribadi. Hasil penelitian menunjukan bahwa variabel kualitas pelayanan berpengaruh positif dan signifikan terhadap kepatuhan wajib pajak.

Penelitian sebelumnya juga pernah dilakukan oleh Boy (2010) mengemukakan bahwa kualitas pelayanan memiliki hubungan yang erat dengan kepatuhan wajib pajak. Berdasarkan hasil-hasil penelitian sebelumnya, maka dapat dirumuskan sebagai berikut:

$\mathrm{H}_{1}$ : Kualitas Pelayanan Account Representativeberpengaruh positif terhadap kepatuhan Wajib Pajak Orang Pribadi di KPP Denpasar Timur.

Berdasarkan teori atribusi, preferensi risiko merupakan kekuatan internal (internal forces) dalam mendorong wajib pajak memenuhi kewajiban 
perpajakannya. Penelitian dari Alabede, Ariffin, dan Idris (2011) menggunakan teori prospek untuk memprediksi pengaruh preferensi risiko memoderasi hubungan antara persepsi kualitas pelayanan fiskus dan kepatuhan wajib pajak. Hasil penelitian Alabede et al (2011) menunjukkan bahwa preferensi risiko berpengaruh negatif dan tidak signifikan dalam memoderasi hubungan antara persepsi tentang kualitas pelayanan fiskus dan kepatuhan wajib pajak. Hasil penelitian Alabede et al., (2011) didukung oleh penelitian yang dilakukan oleh Feld dan Frey (2006), Kirchler E, Hoelzl E (2007), Frey dan Torgler (2007) dan Aryobimo dan Cahyonowati (2012). Berdasarkan hasil-hasil penelitian sebelumnya, maka dapat dirumuskan sebagai berikut:

$\mathrm{H}_{2}$ : Preferensi Risiko memperlemah hubungan antara kualitas pelayanan Account Representativedengan kepatuhan wajib pajak orang pribadi.

\section{METODE PENELITIAN}

Penelitian ini dilakukan di wilayah Denpasar tepatnya di Kantor Pelayanan Pajak (KPP) Pratama Denpasar Timur yang beralamat di Jalan Letda Tantular No.4 Renon, Denpasar.Populasi dalam penelitian ini adalah 76.543 Wajib Pajak Orang Pribadi efektif yang terdaftar di KPP Denpasar Timur berdasarkan data yang diperoleh dari KPP Pratama Denpasar Timur. Guna efisiensi waktu dan biaya maka peneliti melakukan pengambilan sampel.Sampel pada penelitian akan dipilih sedemikian rupa sehingga dapat mewakili sifat-sifat populasi (Sugiyono, 2014). Jumlah sampel ditentukan dengan rumus Slovin berikut:

$$
n=\frac{N}{1+N e^{2}}
$$


Ni Kadek Ayu Disnayanti dan I.G.A. Agung Pradnya Dewi. Moderasi ...

Keterangan :

$\mathrm{N}=$ Jumlah populasi

$\mathrm{n}=$ Sampel

$\mathrm{e}^{2}=$ Persen kesalahan pengambilan sampel $(10 \%)$

Berdasarkan data yang diperoleh dari KPP Pratama Denpasar Timur, diketahui jumlah populasi wajib pajak orang pribadi efektif yang terdaftar per 31 Desember 2017 sebanyak 76.543 orang. Dengan menggunakan rumus slovin, maka besarnya sampel penelitian ini adalah:

$$
\begin{gathered}
n=\frac{76.543}{1+76.543(0,1)^{2}} \\
n=99,99 \\
n=100 \text { (dibulatkan) }
\end{gathered}
$$

Berdasarkan perhitungan di atas, banyaknya sampel yang diambil pada penelitian ini adalah sebanyak 99,90 yang dibulatkan menjadi 100 Wajib Pajak Orang Pribadi.

Teknik analisis data yang digunakan dalam penelitian ini adalahmoderated regression analysis (MRA). Model regresi dalam penelitian ini ditunjukkan dengan persamaan sebagai berikut:

$$
Y=\alpha+\beta_{1} X+\beta_{2} Z+\beta_{3} X Z+\varepsilon
$$

Keterangan :

$\mathrm{Y}_{\mathrm{i}}=$ Kepatuhan Wajib Pajak Orang Pribadi

$\alpha=$ Bilangan Konstanta

$B=$ Koefisien arah persamaan penelitian

$\mathrm{X}=$ Kualitas Pelayanan Account Representative

$\mathrm{Z}=$ Preferensi Risiko

$\varepsilon=$ Kesalahan pengganggu 


\section{HASIL DAN PEMBAHASAN}

Karakteristik responden dibagi menjadi beberapa kelompok menurut jenis kelamin digunakan untuk mengetahui proporsi wajib pajak orang pribadi laki-laki dan perempuan, usia digunakan untuk mengetahui rentang umur WPOP, serta tingkat pendidikan yang digunakan untuk mengetahui tingkat pengetahuan dan intelektualitas yang dimiliki oleh WPOP dalam mematuhi ketentuan perpajakan. Rincian profil responden disajikan pada Tabel 3.

Tabel 3.

Karakteristik Responden Penelitian

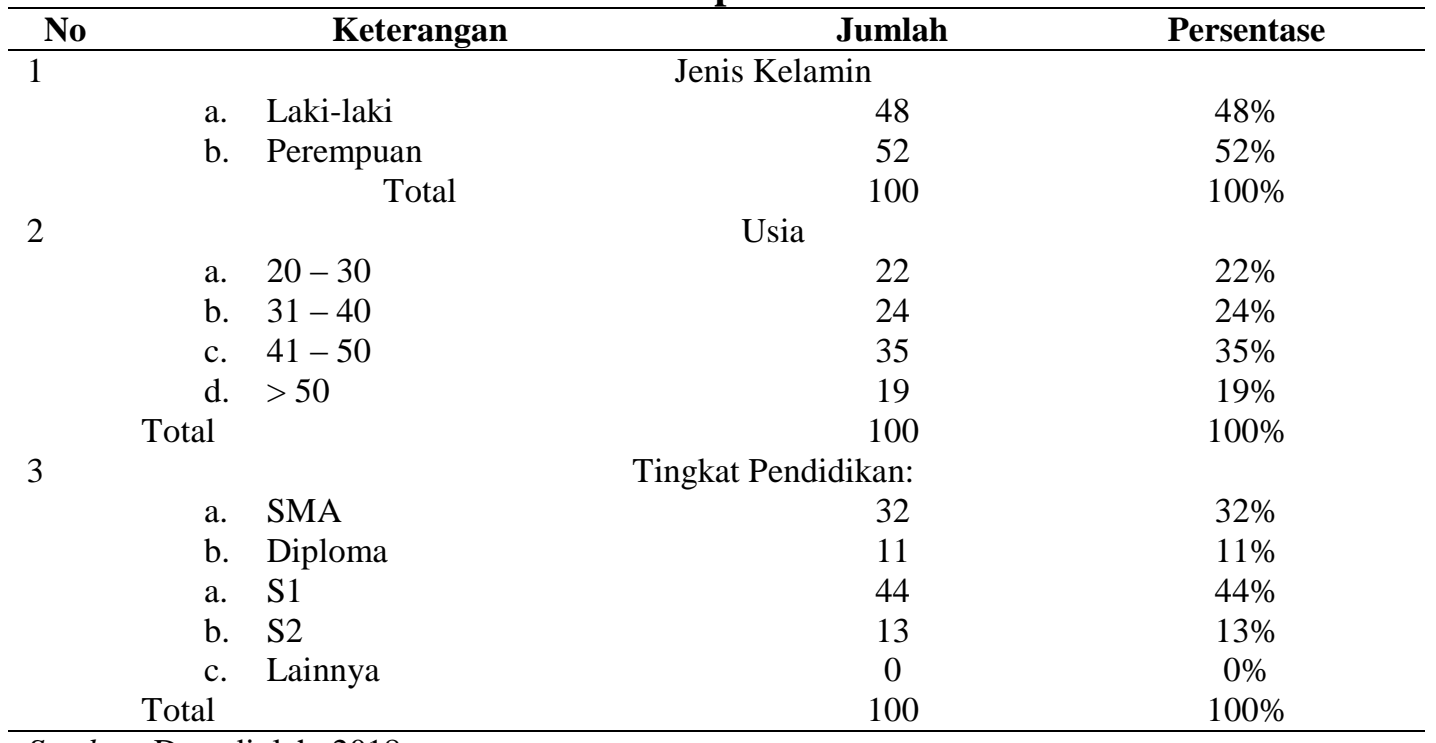

Sumber: Data diolah, 2018

Jenis kelamin responden dapat digunakan sebagai acuan untuk mengetahui proporsi wajib pajak orang pribadi antara laki-laki dan perempuan dalam memenuhi kewajiban perpajakannya. Pada Tabel 3 dapat dilihat bahwa responden berjenis kelamin laki-laki yaitu sebanyak 48 orang dan sisanya berjenis kelamin perempuan sebanyak 52 orang. Hal ini menunjukkan bahwa mayoritas responden penelitian ini adalah perempuan. 
Ni Kadek Ayu Disnayanti dan I.G.A. Agung Pradnya Dewi. Moderasi ...

Usia responden menggambarkan kedewasaan dan pengalaman seseorang. Pada Tabel 3 dapat dilihat wajib pajak pada usia 20-30 tahun cenderung memanfaatkan aplikasi $e$-spt, e-filling, e-billing dan sistem elektronik lainnya untuk memenuhi kewajiban perpajakannya sehingga persentase karakteristik responden pada penelitian ini sebesar 22 persen. Jumlah tertinggi responden penelitian ini yaitu berusia 40-50 tahun sebesar 35 persen disebabkan pada usia tersebut wajib pajak dalam memenuhi kewajiban perpajakannya memilih untuk datang langsung ke kantor pelayanan pajak. Hal tersebut yang mengindikasikan mayoritas responden penelitian ini merupakan usia 40-50 tahun.

Tingkat pendidikan responden dapat digunakan sebagai indikator untuk mengetahui tingkat pengetahuan dan intelektualitas yang dimiliki oleh responden dalam mematuhi ketentuan perpajakan. Semakin tinggi tingkat pendidikan wajib pajak, maka kepatuhan wajib pajak akan semakin meningkat. Berdasarkan Tabel 3 dapat dilihat bahwa responden dengan tingkat pendidikan S1 berada di posisi tertinggi yaitu sebanyak 44 orang atau 44 persen. Artinya, WPOP efekif yang terdaftar di KPP Denpasar Timur memiliki tingkat intelektualitas yang tinggi sehingga nantinya diharapkan tingkat kepatuhan wajib pajak juga mudah untuk ditingkatkan. Tingginya tingkat pendidikan memungkinkan seseorang untuk lebih bertanggung jawab, lebih banyak menyerap pengetahuan tentang perpajakan, serta lebih sadar akan hak dan kewajibannya sebagai wajib pajak.

Kuesioner yang digunakan dalam suatu penelitian haruslah valid, yaitu kuesioner yang mampu mengungkapkan apa yang diukur dengan kuesioner 
tersebut. Validnya suatu kuesioner dapat dilihat dari nilai $\mathrm{r}$ hitung yang lebih besar dari 0,30. Hasil uji validitas disajikan pada Tabel 4.

Tabel 5.

Hasil Uji Validitas

\begin{tabular}{llccc}
\hline No & \multicolumn{1}{c}{ Variabel } & Kode Instrumen & $\begin{array}{c}\text { Koefisien } \\
\text { Korelasi }\end{array}$ & Keterangan \\
\hline $\mathbf{1}$ & Kualitas & X.1 & 0,755 & Valid \\
& Pelayanan & X.2 & 0,721 & Valid \\
& Account & X.3 & 0,603 & Valid \\
& Representative & X.4 & 0,822 & Valid \\
& (X) & X.5 & 0,365 & Valid \\
& Kepatuhan Wajib & X.6 & 0,788 & Valid \\
& Pajak Orang & Y.2 & 0,610 & Valid \\
& Pribadi (Y) & Y.3 & 0,707 & Valid \\
& & Y.4 & 0,658 & Valid \\
& & Y.5 & 0,651 & Valid \\
& & Y.6 & 0,473 & Valid \\
& & Y.7 & 0,736 & Valid \\
& & Y.8 & 0,657 & Valid \\
& & Z.1 & 0,671 & Valid \\
& Preferensi Risiko & Z.2 & 0,645 & Valid \\
& (Z) & Z.3 & 0,505 & Valid \\
& & 0,721 & Valid \\
& Z.4 & 0,746 & Valid \\
& Z.5 & 0,784 & Valid \\
& & Z.6 & 0,710 & Valid \\
& Z.8 & 0,590 & Valid \\
& & 0,467 & Valid \\
& & 0,590 & Valid \\
& & 0,601 & Valid \\
& & 0,405 & Valid \\
\hline
\end{tabular}

Sumber: Data diolah, 2018

Berdasarkan Tabel 5 menunjukkan bahwa instrumen penelitian yang terdiri dari item-item pernyataan kualitas pelayanan account representative (X), kepatuhan wajib pajak orang pribadi $(Y)$, dan preferensi risiko $(\mathrm{Z})$ memiliki nilai koefisien korelasi yang lebih besar dari 0,30. Jadi, seluruh indikator pernyataan tersebut telah memenuhi syarat validitas data.

Uji reliabilitas digunakan untuk mengukur konsistensi hasil pengukuran dari kuesioner dalam penggunaan yang berulang. Uji reliabilitas dalam penelitian ini menggunakan Cronbach Alpha dengan kriteria pengambilan keputusan 
Ni Kadek Ayu Disnayanti dan I.G.A. Agung Pradnya Dewi. Moderasi ...

sebagaimana dinyatakan oleh (Ghozali, 2016:43), yaitu jika koefisien Cronbach Alpha $(\alpha)>0,7$ maka pertanyaan/pernyataan dinyatakan andal. Hasil uji reliabilitas disajikan pada Tabel 6.

Tabel 6.

Hasil Uji Reliabilitas

\begin{tabular}{clccc}
\hline No & \multicolumn{1}{c}{ Variabel } & Cronbach's Alpha & Keterangan \\
\hline 1 & $\begin{array}{l}\text { Kualitas } \\
\text { Representative (X) }\end{array}$ & 0,764 & Reliabel \\
3 & $\begin{array}{l}\text { Kepatuhan } \\
\text { (Y) }\end{array}$ & 0,797 & Reliabel \\
3 & Preferensi Risiko $(\mathrm{Z})$ & 0,833 & Reliabel \\
\hline
\end{tabular}

Sumber: Data diolah, 2018

Berdasarkan Tabel 6 menunjukkan bahwa nilai Cronbach Alpha masingmasing variabel lebih besar dari 0,70. Sehingga, dapat disimpulkan bahwa pernyataan dalam kuesioner penelitian ini reliabel dan dapat digunakan.

Statistik deskriptif memberikan gambaran umum tentang karakteristik variabel-variabel penelitian dengan menggunakan nilai minimum, maksimum, nilai rata-rata, dan standar deviasi. Hasil pengujian statistik deskriptif disajikan pada Tabel 7 .

Tabel 7.

Hasil Analisis Statistik Deskriptif

\begin{tabular}{|c|c|c|c|c|c|}
\hline Variabel & $\mathbf{N}$ & Min & $\operatorname{Max}$ & Mean & Std.Deviation \\
\hline $\begin{array}{l}\text { Kualitas Pelayanan Account } \\
\text { Representative (X) }\end{array}$ & 100 & 12 & 24 & 19,5 & 2,134 \\
\hline Preferensi Risiko (Z) & 100 & 19 & 44 & 31,32 & 4,653 \\
\hline $\begin{array}{l}\text { Kepatuhan Wajib Pajak Orang } \\
\text { Pribadi (Y) }\end{array}$ & 100 & 12 & 32 & 25,47 & 3,454 \\
\hline Valid N (listwise) & 100 & & & & \\
\hline
\end{tabular}

Berdasarkan Tabel 7 dapat disimpulkan bahwa jumlah pengamatan $(\mathrm{N})$ penelitian ini berjumlah 100 . Variabel kualitas pelayanan account representative memiliki nilai minimum sebesar 12 dan nilai maksimum sebesar 24 dengan nilai rata-rata sebesar 19,45 yang apabila dibagi dengan 6 item pernyataan akan 
menghasilkan nilai sebesar 3,24. Hal ini berarti rata-rata responden memberikan skor 3 pada setiap item pernyataan variabel kualitas pelayanan account representative. Standar deviasi pada variabel ini sebesar 2,134 yang menunjukkan bahwa standar penyimpangan data terhadap nilai rata-ratanya adalah 2,134.

Variabel preferensi risikomemiliki nilai minimum sebesar 19 dan nilai maksimum sebesar 44 dengan nilai rata-rata sebesar 31,32 yang apabila dibagi dengan 11 item pernyataan akan menghasilkan nilai sebesar 2,85. Hal ini berarti rata-rata responden memberikan skor 3 pada setiap item pernyataan variabel preferensi risiko. Standar deviasi pada variabel ini sebesar 4,653 yang menunjukkan bahwa standar penyimpangan data terhadap nilai rata-ratanya adalah 4,653.

Variabel kepatuhan wajib pajak orang pribadi memiliki nilai minimum sebesar 12 dan nilai maksimum sebesar 32 dengan nilai rata-rata sebesar 25,47 yang apabila dibagi dengan 8 item pernyataan akan menghasilkan nilai sebesar 3,18. Hal ini berarti rata-rata responden memberikan skor 3 pada setiap item pernyataan variabel kepatuhan wajib pajak orang pribadi. Standar deviasi pada variabel ini sebesar 4,653 yang menunjukkan bahwa standar penyimpangan data terhadap nilai rata-ratanya adalah 4,653.

Koefisien determinasi digunakan untuk mengukur sejauh mana kemampuan variabel independen dalam menerangkan variasi variabel dependen. Hasil uji koefisien determinasi disajikan pada Tabel 8. 
Tabel 8.

Hasil Uji Koefisien Determinasi

\begin{tabular}{|c|c|c|c|c|}
\hline Model & $\mathbf{R}$ & R Square & Adjusted R Square & $\begin{array}{l}\text { Std. Error of the } \\
\text { Estimate }\end{array}$ \\
\hline 1 & $.674^{\mathrm{a}}$ & .454 & .437 & 2.59 \\
\hline
\end{tabular}

Berdasarkan Tabel 8 Angka adjusted $R$ square sebesar 43,7 persen menunjukkan bahwa hanya 43,7 persen variabel kepatuhan wajib pajak orang pribadi yang bisa dijelaskan oleh variabel kualitas pelayanan account representative, sisanya 56,3 persen dijelaskan faktor lain.

Uji kelayakan model (uji F) dilakukan untuk menguji apakah variabel independen yang digunakan bersifat layak digunakan atau tidak sebagai penjelas atau prediktor. Hasil uji F disajikan pada Tabel 9.

Tabel 9.

Hasil Uji F

\begin{tabular}{llrrrrr}
\hline Model & & Sum of Squares & df & Mean Square & \multicolumn{1}{l}{ F } & \multicolumn{1}{c}{ Sig. } \\
\hline 1 & Regression & 536.476 & 3 & 178.825 & 26.639 & $.000^{\mathrm{a}}$ \\
& Residual & 644.434 & 96 & 6.713 & & \\
& Total & 1180.910 & 99 & & & \\
\hline
\end{tabular}

Sumber: Data diolah, 2018

Dari Tabel 9 diatas, nilai signifikansi $\mathrm{F}$ adalah sebesar 0,000 yang lebih kecil dari 0,05. Hal ini menunjukkan kualitas pelayanan account representative, preferensi risiko, serta interaksi antara kualitas pelayanan account representative dan preferensi risiko berpengaruh secara bersama-sama terhadap kepatuhan wajib pajak orang pribadi. Hal ini berarti model dalam penelitian ini layak digunakan (fit).Uji hipotesis (uji t) dilakukan untuk mengetahui apakah ada pengaruh yang signifikan antara variabel bebas terhadap variabel terikat.Level of significant $(\alpha)$ yang digunakan adalah 5 persen. $\mathrm{H}_{\mathrm{i}}$ diterima jika $p$-value $<\alpha=0,05$. Berdasarkan 
Tabel 10 hasil pengujian pengaruh masing-masing variabel bebas terhadap variabel terikat dapat dijabarkan sebagai berikut.

\section{Tabel 10.}

Hasil Uji t

\begin{tabular}{llrrrrr}
\hline & \multicolumn{7}{c}{ Unstandardized Coefficients } & \multicolumn{2}{c}{$\begin{array}{c}\text { Standardized } \\
\text { Coefficients }\end{array}$} \\
Model & & B & Std. Error & \multicolumn{1}{c}{ Beta } & \multicolumn{1}{c}{ T } & \multicolumn{1}{c}{ Sig. } \\
\hline 1 & (Constant) & -36.236 & 14.805 & & -2.448 & .016 \\
& X & 2.756 & .757 & 1.703 & 3.640 & .000 \\
& Z & 1.555 & .470 & 2.095 & 3.307 & .001 \\
& XZ & -.066 & .024 & -2.619 & -2.802 & .006 \\
\hline Sumber: Data diolah, 2018 & & & & &
\end{tabular}

Berdasarkan Tabel 10 menunjukkan t hitung kualitas pelayanan account representative adalah sebesar 3,640 dengan signifikansi $t$ bernilai 0,000 (signifikan) Hal ini berarti Kualitas Pelayanan Account Representative berpengaruh positif terhadap Kepatuhan Wajib Pajak Orang Pribadi. Variabel preferensi risiko mempunyai $\mathrm{t}$ hitung 3,307 dengan signifikansi 0,001 (signifikan).Variabel interaksi antara variabel kualitas pelayanan account representative dan preferensi risiko $\left(\mathrm{X}^{*} \mathrm{Z}\right)$ mempunyai t hitung sebesar $-2,802$ dengan signifikansi 0,006 (signifikan).Hal ini berarti bahwa variabel preferensi risiko merupakan pemoderasi dalam hubungan antara kualitas pelayanan account representative dengan kepatuhan wajib pajak orang pribadi. Preferensi Risiko memperlemah hubungan antara kualitas pelayanan account representative dengan kepatuhan wajib pajak orang pribadi.

Moderated Regression Analysis (MRA) merupakan aplikasi khusus regresi linier berganda dimana dalam persamaan regresinya mengandung unsur interaksi (perkalian dua atau lebih variabel independen), teknik analisis ini dipilih karena penelitian ini dirancang untuk meneliti variabel independen yang berpengaruh 
Ni Kadek Ayu Disnayanti dan I.G.A. Agung Pradnya Dewi. Moderasi ...

terhadap variabel dependen dengan menggunakan variabel moderasi. Perhitungan akan dianggap signifikan jika nilai ujinya berada dalam daerah kritis (daerah dimana $\mathrm{H}_{0}$ ditolak). Namun, jika nilai uji berada di daerah luar kritis $\left(\mathrm{H}_{0}\right.$ diterima), maka perhitungan statistiknya tidak signifikan.Berdasarkan 10 dapat disusun persamaan regresi sebagai berikut:

$$
Y=-36,236+2,756 X+1,555 Z+(-0.066) X Z+\varepsilon
$$

Nilai konstanta sebesar -36,236 menunjukkan bahwa bila nilai kualitas pelayanan account representative $(\mathrm{X})$, preferensi risiko $(\mathrm{Z})$ dan interaksi antara kualitas pelayanan account representative dan preferensi risiko (XZ) sama dengan nol, maka nilai kepatuhan wajib pajak orang pribadi (Y) menurun sebesar 36,236 satuan.

Nilai koefisien $\beta_{1}=2,756$ berarti menunjukkan bila kualitas pelayanan account representative $(\mathrm{X})$ bertambah 1 satuan, maka nilai dari kepatuhan wajib pajak orang pribadi (Y) akan mengalami peningkatan sebesar 2,756 satuan dengan asumsi variabel bebas lainnya konstan.

Nilai koefisien $\beta_{2}=1,555$ berarti menunjukkan bila preferensi risiko $(\mathrm{Z})$ bertambah 1 satuan, maka nilai dari kepatuhan wajib pajak orang pribadi (Y) akan mengalami peningkatan sebesar 1,555 satuan dengan asumsi variabel bebas lainnya konstan.

Nilai koefisien $\beta_{3}=-0.066$ mengindikasikan bahwa interaksi antara kualitas pelayanan account representative dan preferansi risiko (XZ) berpengaruh negatif terhadap kepatuhan wajib pajak orang pribadi. Hal ini menunjukkan bahwa dengan penambahan satu satuan interaksi antara kualitas pelayanan 
account representative dan preferensi risiko maka akan terjadi penurunan sebesar 0,006 .

Berdasarkan Tabel 10 nilai signifikansi $\mathrm{t}$ untuk variabel kualitas pelayanan account representative sebesar 0,000 yang lebih kecil dari $\alpha=0,05$. Hal ini menunjukkan hipotesis pertama dalam penelitian ini diterima yaitu, kualitas pelayanan account representative berpengaruh positif terhadap kepatuhan wajib pajak orang pribadi di Kantor Pelayanan Pajak Pratama Denpasar Timur.

Teori atribusi menjelaskan bahwa perilaku seseorang itu ditentukan oleh kombinasi antara kekuatan internal (internal forces) dan kekuatan eksternal.Berdasarkan teori atribusi, kualitas pelayanan account representative merupakan kekuatan eksternal dalam mendorong wajib pajak memenuhi kewajiban perpajakannya.Kualitas pelayanan menjadi kunci bagi aparat untuk meningkatkan penerimaan pajak dan kepuasan wajib pajak terhadap kinerja account representative. Kualitas pelayanan memiliki hubungan yang erat dengan kepatuhan wajib pajak, kualitas memberikan suatu dorongan kepada wajib pajak untuk menjalin suatu hubungan yang dinamis dengan Kantor Pelayanan Pajak (KPP). Hasil penelitian ini konsisten dengan penelitian yang dilakukan oleh Sumardi (2005) dan Verisca Dena (2010).

Berdasarkan Tabel 10 nilai signifikansi t menunjukkan interaksi antara kualitas pelayanan account representative dan preferensi risiko $\left(\mathrm{X}^{*} \mathrm{Z}\right)$ berpengaruh negatif pada kepatuhan wajib pajak orang pribadi dengan signifikansi sebesar 0,006 yang lebih kecil dari dari $\alpha=0,05$. Hal ini menunjukkan hipotesis kedua dalam penelitian ini diterima yaitu, preferensi risiko 
Ni Kadek Ayu Disnayanti dan I.G.A. Agung Pradnya Dewi. Moderasi ...

memperlemah hubungan antara kualitas pelayanan Account Representative dengan kepatuhan wajib pajak orang pribadi.

Berdasarkan teori atribusi, preferensi risiko merupakan kekuatan internal (internal forces) dalam mendorong wajib pajak memenuhi kewajiban perpajakannya. Preferensi risiko sebagai variabel moderasi dan secara operasional didefinisikan sebagai risiko atau peluang yang akan dipertimbangkan oleh wajib pajak yang menjadi prioritas utama diantara yang lainnya dari berbagai pilihan yang tersedia (Atkins, Godfarb, Kerps, Rogers, Schoolman \& Van Odrop, 2005; Guthrine, 2003). Ketika kepatuhan pajak memiliki hubungan yang kuat dengan preferensi risiko maka tingkat kepatuhan wajib pajak akan rendah artinya wajib pajak memiliki berbagai risiko yang tinggi akan dapat menurunkan tingkat kepatuhan wajib pajak (Aryobimo dan Cahyonowati, 2012).

Dalam penelitian ini menunjukkan bahwa, preferensi risiko memperlemah hubungan antara kualitas pelayanan Account Representative dengan kepatuhan wajib pajak orang pribadi.Pernyataan tersebut diperkuat oleh penelitian Alabede et al (2011) menunjukkan bahwa preferensi risiko berpengaruh negatif dalam memoderasi hubungan antara persepsi tentang kualitas pelayanan fiskus dan kepatuhan wajib pajak.Hasil penelitian Alabede et al., (2011) didukung oleh penelitian yang dilakukan oleh Feld dan Frey (2006), Kirchler E, Hoelzl E (2007), Frey dan Torgler (2007) dan Aryobimo dan Cahyonowati (2012). 


\section{SIMPULAN}

Dalam upaya untuk meningkatkan kepatuhan wajib pajak, Kantor Pelayanan Pajak Pratama Denpasar Timur yang merupakan instansi vertikal di bawah Kantor Wilayah Direktorat Jenderal Pajak harus terus meningkatkan kualitas pelayanan pajak melalui account representative maupun fasilitas lainnya,. Dalam upaya meningkatkan sistem administrasi perpajakan modern di Kantor Pelayanan Pajak Pratama Denpasar Timur, sebaiknya petugas pajak secara rutin melakukan sosialisasi kepada wajib pajak.Hal-hal tersebut dapat mendorong wajib pajak untuk patuh dalam melaksanakan kewajiban perpajakannya.Hal ini mengandung implikasi agar dalam memberikan layanan kepada wajib pajak, petugas pajak memenuhi kriteria 4K yaitu, keamanan, kenyamanan, kelancaran, dan kepastian hukum. Layanan yang berkualitas dapat meningkatkan kepercayaan wajib pajak dalam melaksanakan kewajiban perpajakannya dengan sukarela.

Jika tertarik meneliti di bidang yang sama dapat menggunakan variabelvariabel yang tidak digunakan dalam penelitian ini, hal ini dilakukan karena koefesien determinasi dalam penelitian ini masih dapat ditingkatkan dengan adanya penambahan variabel bebas. Variabel bebas yang dapat digunakan untuk penelitian selanjutnya yaitu fungsi account representative selain penelitian ini. Fungsi account representative lain selain penelitian ini yaitu pengawasan account representative dan konsultasi account representative. Hendaknya menambahkan indikator atau jumlah pertanyaan untuk setiap variabel penelitian agar hasil penelitian lebih baik. Untuk memperbanyak jumlah responden dan juga 
memperluas ruang lingkup penelitian, hal ini agar memperoleh jawaban dan hasil penelitian yang lebih baik.

\section{REFERENSI}

Alabede, J. O., Ariffin, Z. Z., \& Idris, K. M. (2011). Individual taxpayers ' attitude and compliance behaviour in Nigeria: The moderating role of financial condition and risk preference. Journal of Accounting and Taxation, 3(September), 91-104.

Arfan, I, L. (2010). Akuntansi Keperilakuan (Edisi dua). Jakarta: Salemba Empat.

Arikunto. (2010). Prosedur Penelitian Suatu Pendekatan Praktik. Jakarta: Rineka Cipta.

Aryobimo, P. T., \& Cahyonowati, N. (2012). Pengaruh Persepsi Wajib Pajak tentang Kualitas Pelayanan Fiskus terhadap Kepatuhan Wajib Pajak dengan Kondisi Keuangan Wajib Pajak dan Preferensi Risiko sebagai Variabel Moderating (Studi Empiris terhadap Wajib Pajak Orang Pribadi di Kota Semarang). Diponegoro Journal Of Accounting, 1(2), 1-12.

Atkins J, Goldfarb R, Kerps RE, Rogers K, Schoolman P, V. O. (2005). Elisitasi dan Penjelasan preferensi risiko. Casualty, 128.

Boy, N. (2010). Analisis Pengaruh Pelayanan, Konsultasi, dan Pengawasan Account Representative terhadap Kepatuhan Wajib Pajak (Studi Empiris Pada Kantor Pelayanan Pajak Tangerang dan Serpong).

Das-gupta, A. (2004). Tax Administration Reform and Taxpayer Compliance in India, 575-600.

Feld, L. P., \& Frey, B. S. (2006). Tax compliance as the result of a psychological tax contract: The role of incentives and responsive regulation. Law and Policy, 29(1), 102-120. https://doi.org/10.1111/j.1467-9930.2007.00248.x

Frey, B. S., \& Torgler, B. (2007). Tax Morale and Conditional Cooperation. Journal of Comparative Economics. Journal of Comparative Economics, 35(1), 136-159.

Khasanah, S. N. (2014). Pengaruh Pengetahuan Perpajakan, Modernisasi Sistem Administrasi Perpajakan, Dan Kesadaran Wajib Pajak Terhadap Kepatuhan Wajib Pajak Pada Kantor Wilayah Direktorat Jenderal Pajak Daerah Istimewa Yogyakarta Tahun 2013. 
Kirchler E, Hoelzl E, W. I. (2007). Enforced Versus Voluntary Tax Compliance: The Slippery Slope Framework. Journal Of Economy Psychology, 29(2), 210-225.

Mardiasmo. (2016). Perpajakan Edisi Terbaru 2016. Yogyakarta: Penerbit Andi.

Masruroh, S., \& Z. (2013). Pengaruh Kemanfaatan NPWP, Pemahaman Wajib Pajak, Kualitas Pelayanan, Sanksi Perpajakan terhadap Kepatuhan Wajib Pajak pada WPOP di Kabupaten Tegal. Diponegoro Journal of Accounting.

Muhammarsyah, N. (2011). Pengaruh Peran Account Representative, Pemahaman Prosedur Perpajakan Wajib Pajak, dan Kualitas Pelayanan Tempat Pelayanan Terpadu diKantor Pajak Terhadap Kepatuhan Wajib Pajak dalam Memenuhi Kewajiban Perpajakannya (Studi Kasus Pada Delapan Kantor Pelayan. Fakultas Ekonomi Dan Bisnis Universitas Islam Negeri Syarif Hidayatullah.

Nicholson, Soane, Fenton-O’Creevy, \& W. (2005). Personality and Domain RiskSpecific Risk Taking, 8(2).

Nunnally, Bernstein, I.H. (1994) (Edisi ke 3). New York: McGraw Hill.

Pandan, S. H. (2014). Pengaruh Pengetahuan Perpajakan, Kualitas Pelayanan, Pemeriksaan Dan Kesadaran Terhadap Kepatuhan Wajib Pajak (Studi Empiris Terhadap Karyawan Kantor Badan Pusat Statistik Jember).

Parasuraman, Zeithaml, dan B. (1988). SERVQUAL : A Multiple-Item Scale for Measuring Consumer Perception of Service Quality. Journal of Retailing. Marketing Science Institute.

Prasetyo, A. D. (2012). Pengaruh Kualitas Pelayanan Acoount Representative (AR) terhadap Kepuasan dan Kepatuhan Wajib Pajak Orang Pribadi (Studi kasus pada KPP Pratama Malang Utara). Jurusan Akuntansi.

Rahayu, S. K. (2010). PERPAJAKAN INDONESIA: Konsep dan Aspek Formal. Yogyakarta: Graha Ilmu.

Rahayu, S., \& Lingga, I. S. (2009). Pengaruh Modernisasi Sistem Administrasi Perpajakan Terhadap Kepatuhan Wajib Pajak. Jurnal Akuntansi Universitas Kristen Maranatha, 1(2), 119-138.

Rosady, I. S. (2014). Pengaruh Kualitas Pelayanan Pajak dan Kinerja Account Representative (AR) terhadap Kepatuhan Perpajakan.

Sadjiarto, R. I. dan A. (2013). Pengaruh Account Representative Terhadap Kepatuhan Wajib Pajak Di KPP Pratama Tarakan, 3(2). 
Sitkin, S. B., and A. L. P. . (1992). Reconceptualizing the Determinants of Risk 9-38., Behavior. Academy of Management Review 17.

Sondakh; Jullie Jeanette. (2017). Behavioral Intention to Use E-Tax Service System: An Application of Technology Acceptance Model. European Research Studies Journal Volume XX, 2(2), 48-64.

Sovita, I., \& Salsabilla, A. (2018). Pengaruh Peran Account Representative Terhadap Tingkat Kepatuhan Wajib Pajak Orang Pribadi (Studi Kasus Pada Kantor Pelayanan Pajak Pratama Padang Satu). Jurnal Ekonomi \& Bisnis Dharma Andalas, 20(2), 258-267.

Supadmi, N. L. (2009). Meningkatkan Kepatuhan Wajib Pajak Melalui Kualitas Pelayanan. Jurnal Ilmiah Akuntansi Dan Bisnis, 4(2).

Suratningsih, N. P., \& M, N. K. L. A. (2018). E-Jurnal Akuntansi Universitas Udayana Pengaruh Penerapan Sistem e-Filling dan Peran Account Representative Pada Kepatuhan Wajib Pajak Orang Pribadi Fakultas Ekonomi dan Bisnis Universitas Udayana ( Unud ), Bali , Indonesia Fakultas Ekonomi dan Bisnis Uni. E-Jurnal Akuntansi Universitas Udayana, 24(2), 1220-1247.

Torgler, B. (2003). To Evade Taxes Or Not To Evade: That Is The Question, Journal Of Socio Economics, 283-302.

Tresno, Indra, W. (2012). Pengaruh Penambahan Wajib Pajak Badan, Penyampaian SPT Masa PPh Badan, dan Pengawasan Kepatuhan Wajib Pajak Badan Terhadap Penerimaan Pajak Penghasilan Badan di KPP Pratama Jakarta Matraman. Universitas Negeri Jakarta.

Wardani, E. A. (2011). Pengaruh Kualitas Pelayanan dan Efektifitas Pengawasan Account representative terhadap Kepatuhan Formal Wajib Pajak.

Werther, W. B., \& Davis, K. (1996). Human Resources And Personal Management. International Edition (Internatio). New York: McGraw-Hiil.

Yulianty, E. (2015). Pengaruh Pemahaman Peraturan Perpajakan Terhadap Kepatuhan Formal Wajib Pajak Dengan Preferensi Risiko Sebagai Variabel Moderating (Studi Kasus Pada Wpop Kpp Pratama Makassar Utara). Skripsi FEB Universitas Hasanuddin Makassar. 